\title{
PREDIKSI PRODUKTIFITAS KERJA PADA PEKERJAAN TA- NAH DAN PONDASI BANGUNAN TAK BERTINGKAT
}

\author{
Sugiyanto, Made wena
}

\begin{abstract}
Abstrak:Kelompok pekerja bangunan yang mengerjakan jenis pekerjaan pengalian tanah, pasangan anstampeng batu kali, pasangan pondasi batu kali, dan pasangan rolag diatas pondasi masih perlu mendapat perhatian, terutama munculnya faktor pengaruh ekternal dan internal dalam bekerja, sehinga mengurangi capaian hasil kerja yang masih rendah dan kurang memberi keuntungan terhadap jasa pelaksana konstruksi. Penelitian mengunakan cara survei, wawancara dan observasi hasil kerja pada setiap jenis pekerjaan konstruksi kepada kelompok pekerja dari pekerja, tukang, mandor dan pelaksana di kota Malang bekerja pada jasa pengembang bangunan tak bertingkat. Hasil penelitian diperoleh sumbangan atribut pada sosio ekonomi meliputi: pengalamam profesi pekerja antara 5-7 th, pendidikan formal yang dicapai sebelum bekerja min SD, Pelatihan ketrampilan kerja yang diperoleh melalui belajar dari tukang atasan, upah satuan harian,Jarak timbunan material kerja terhadap tempat pasangan komponen konstruksi, dan penataan site material dan tempat kerja konstruksi.sumbangan pada lingkungan sarana kerja meliputi variabel: site lokasi pekerjaan konstruksi, ketersediaan material sebelum mengawali pekerjaan konstruksi, kelengkapan peralatan kerja bantu yang dimiliki oleh masing profesi, cara mengunakan material dan metode kerja, Kondisi Cuaca saat berlangsung jam kerja, Profesi tetap sebagai tenaga kerja disektor bangunan, Koefisien upah dari kelompok pekerja dari jenis pekerjaan diperoleh dari hasil capaian produktivitas kerja real dilapangan dalam ukuran waktu kerja 7 jam sehari.
\end{abstract}

Kata-kata kunci: produktivitas, Jenis pekerja bangunan, koefisien upah kerja

Abstract: The group of construction workers who performs the type of earth excavation work, river stone masonry pairs, river stone foundation pairs, and rollerag pairs on the foundation still need attention, especially the emergence of external and internal influencing factors in their work, thereby reducing low and insufficient performance. provide benefits for construction implementation services. The research used surveys, interviews and observations of the work results of each type of construction work to groups of workers, from workers, masons, foremen and implementers in Malang to work in multilevel building developer services. The results showed that the contribution of attributes to the socio-economy includes: professional experience of workers between 5-7 years, formal education achieved before working at elementary school, work skills training obtained through learning from a superior, daily unit wages, distance of work material hoarding to the partner's place. construction components, and the arrangement of site material and construction workplaces. contributions to the work facility environment include variables: construction work site sites, availability of materials before starting construction work, completeness of work tools owned by each profession, how to use materials and work methods, conditions Weather during working hours, permanent profession as labor in the building sector, the wage coefficient of the group of workers from the type of work is obtained from the results of real work productivity achievements in the field in terms of working time of 7 hours a day.

Keywords: productivity, type of construction worker, coefficient of wages

Sugiyanto dan Made Wena adalah Dosen Jurusan Teknik Sipil Fakultas Teknik UM; Jalan Semarang No.5 Malang

65145; E-mail: sugiyanto.ft@um.ac.id, madewena.ft@um.ac.id 


\section{PENDAHULUAN}

Pekerjaan konstruksi bangunan akan dapat bersaing dalam memperoleh pekerjaan dan menghindari spekulasi taksiran biaya yang rendah dalam bekerja, karena pekerja bangunan sebagai tenaga musiman sangat berbeda dengan pekerja lainnya, dan kelompok pekerja dari jenis pekerjaaan tidak bergitu solid dari personal dalam kelompok dan kekompakan. Hal ini perlu mendapatkan memperhatikan dari kondisi internal perkerja dan ekternal di lingkungan kerja, sehingga capaian koefisien produktifitas akan sesuai standar pedoman hasil kerja real. Jasa konstruksi saat ini seharusnya lebih bersiap diri dalam menghadapi faktor pekerja dan lingkungan kerja. sehingga jasa konstruksi/pengembang dituntut agar lebih bersikap kompetitif. Kemampuan kompetitif ini bisa dicapai terutama melalui efisiensi biaya produksi yang dicapai dan pengelolaan waktu pelaksanaan konstruksi rumah (Tjaturono, 2003). Salah satu cara melakukan efisiensi biaya produksi adalah dengan melakukan penghematan biaya tenaga kerja (Sanders, 1993; Budiharto, 1993; Tjaturono, 2003; Satriagung., 2005), Porsi biaya tenaga kerja pada umumnya mencakup 25 35\% dari total biaya pembangunan (Suharto, 1999; Kaming dkk, 1997; Budiharto, 1993). Dengan demikian, jelaslah bahwa untuk menghadapi capain produkifitas setiap jenis pekerjaan dalam bangunan yang dilakukan jasa konstruksi saat ini dan di masa mendatang, dituntut untuk bersikap dan bertindak lebih efisien dalam menerapkan capain hasil kerja agar memiliki nilai kompetitif.

Para pengembang di bidang jasa konstruksi dalam melakukan penentuan satuan produktivitas tenaga kerja masih mengunakan pengalaman dari masing masing pelaku jasa konstruksi, tentang cocok atau kesesuainnya taksiran biaya upah sebenarnya sangat tergantung dari ketelitian dan kondisi saat pengamatan. Zainal, (1992)., dan Soedradjat, (1994). Sebagai contoh, produktivitas tenaga kerja menurut BOW 1921 dan SNI untuk pekerjaan galian tanah biasa yang dilakukan oleh satu tukang gali dalam satu hari menghasilkan volume galian sebesar 1,34 M3 per hari, sedangkan menurut pengalaman Soedradjat (1994), untuk satu tukang galian tanah dalam satu hari kerja menghasilkan minimal 2,1 m3 per hari. Menurut SNI 2001 produktivitas tenaga kerja galian tanah biasa adalah sebesar $3 \mathrm{~m} 3$ per hari, bahkan kondisi dilapangan capain pekerjaan galian tanah dipengaruhi jenis tanah, hasil observasi disaat bekerjaan dilakukan, hasil survei pendahuluan jenis pekerjaan galian jenis tanah hitam kecoklatan diperoleh vulume antara 3-7 m3 per orang hari/ borongan dan begitu pula pada jenis pekerjaan komponen yang lain. Menyadari akan hal itu, maka dirasa perlu dilakukan penelitian yang bertujuan untuk menambah kekurangan dengan cara melakukan penelitian langsung terhadap beberapa pekerja di sektor perusahaan jasa konstruksi swasta guna mendapatkan faktor yang menjelaskan nilai produktivitas kelompok kerja aktual yang sesungguhnya terjadi di lapangan. Dengan demikian,peningkatan produktivitas tenaga kerja di jasa konstruksi akan mudah dilakukan estimasi biaya yang mendekati realitas kerja, sehingga dapat dijadikan pertimbangan dan perbaikan dalam 
menenukan estimasi biaya produksi kerja.

Proses produktivitas kerja diekpresikan bagaimana memanfaatkan sumber daya yang ada ( manusia material alat dan pendukung) dioptimasikan dalam sistem proses secara efisien dan efektif untuk menghasilkan hasil/ produk kerja. Efektifitas dan efisiensi merupakan indikator dari pengukuran produktifitas kerja. Mukhlisani (2008). Sikap mental untuk menyajikan teori teori, kaidah, metode baru dan kepercayaan yang teguh akan kegunaannya bagi umat manusia Ravianto, (1990). Sedangkan menurut Tangen (2002), produktivitas merupakan rasio atau perbandingan antara segala pengorbanan material dan pekerja (input) untuk mewujudkan hasil (output). Sumber daya yang digunakan untuk mewujudkan hasil tersebut antara lain tenaga kerja, modal, termasuk mesin mesin, peralatan, bahan mentah, tenaga listrik, teknologi dan lain lain. Diantara sumber daya tersebut faktor tenaga kerja memegang peranan utama dalam pencapaian tingkat produktivitas tertentu, karena alat bantu produksi, dan cara teknologi pada hakekatnya hasil karya manusia.

Penelitian yang dilakukan oleh Kaming dkk.(1998) menyimbulkan bahwa efisiensi pemanfaatan sumber daya manusia dianggap paling utama, karena pengelolaan sumber daya manusia menjadi hal perlu perhatian. Mulai dari inventarisasi kebutuhan tenaga kerja perhari, waktu perekrutan sampai pembentukan kelompok kerja yang kompak (komposisi tenaga kerja) membutuhkan ketelitian perhatian dan pengendalian yang akurat. Ratnayanti (2003) menyimpulkan pula bahwa efisiensi produktivitas tenaga kerja dapat dicapai melalui penentuan komposisi tukang dengan pembantu tukang dan komunikasi. Demikian pula, Tjaturono (2000) menyatakan bahwa optimasi produktivitas tenaga kerja sangat bergantung pada komposisi tukang dengan pembantu tukang. Dapat disederhanakan bahwa efisiensi tenaga kerja selain ditentukan pengelolaan sumber daya manusia dalam pekejaan juga munculnya variabel varlabel internal dan eksternal dan jenis pekerjaan, juga ditentukan oleh komposisi tenaga kerja pada setiap jenis pekerjaan.

Dengan mengetahui faktor faktor yang mempengaruhi produktivitas kerja maka kemampuan profesi pekerja konstruksi akan dapat terukur dalam menentukan produktivitas aktual real dilapangan. Besarnya jumlah tenaga kerja yang dibutuhkan untuk bagian pekerjaan dalam satu satuan pekerjaan bangunan diukur dalam satuan tertentu mengambarkan capaian fisik (Ibrahim, bachtiar.1994). Sedangkan Anoraga dan Srisuyah (1995) menjelaskan faktor penentu yang mempengaruhi produktivitas tenaga kerja yaitu: motivasi, pendidikan, pengalaman kerja, keterampilan yang diperoleh dari pelatihan kerja, disiplin kerja, lingkungan/iklim kerja, sikap/etika, teknologi alat kerja, jaminan sosial, dan sarana produksi. Begitu pula pendapat Simadjuntak dalam Ravianto, (1990), menjelaskan bahwa produktivitas tenaga kerja dipengaruhi oleh berbagai faktor seperti: pendidikan, keterampilan, pengalaman kerja, disiplin, sikap/etika, motivasi kerja, kesehatan, upah/gaji, lingkungan/iklim, teknologi, sarana produksi, kesempatan berprestasi, dan kebijakan usaha dari pemerintah. Semua faktor yang mempengaruhi produk- 
tivitas di atas bersifat umum yaitu untuk tenaga kerja pada industri/perusahaan, sedangkan faktor penentu produktivitas tenaga kerja bangunan bidang konstruksi masih jarang dibahas dan hanya pada bagian $\neg$ bagian kecil yang telah diteliti. Menurut Kaming dkk. (2000) menyatakan bahwa faktor utama yang mempengaruhi produktivitas tenaga kerja pada pembangunan gedung tidak bertingkat adalah: penyediaan bahan, cuaca saat bekerja, hasil kualitas bangunan, pengalaman kerja, penataan site material dan peralatan bantu kerja. Sementara dari Halligan dkk. (1994), faktor faktor yang menyebabkan penurunan produktivitas tenaga kerja adalah: cuaca saat bekerja, pengadaan bahan, dan jadwal kerja yang overtime, dan Randolph dkk. (1992) menyimpulkan diperoleh faktor faktor yang menyebabkan penurunan/pengurangan produktivitas tenaga kerja pasangan batu adalah: cuaca, ketersediaan/kekurangan material, kecelakaan kerja, kemacetan komunikasi koordinasi, kondisi fisik lokasi peralatan kerja, dan pekerjaan pengulangan/ perbaikan.

Dari hasil uraian di atas dapat disederhanakan bahwa faktor penentu produktivitas pada kajian yang telah dilakukan dari tahun ke tahun mwngalami perubahan yang cenderung meningkat secara bertahap sesuai perubahan kondisi sosio ekonomi, lingkungan sarana kerja. Faktor ini perlu untuk diketahui sejauh mana dapat mempengaruhi produktivitas tenaga kerja disetor pekerjaan tanah dan pasangan komponen pondasi batu kali yang mempengaruhi produktivitas hasil kerja.

Perkiraan upah bagi pekerja bangunan antara lain didasarkan pada kondisi hasil kerja dalam kurun jam/hari yang dilakukan dari unsur pekerja, tukang, mandor dan pelaksana. Dari setiap jenis komponen bangunan dapat diperolah index koefisien upah kerja yang berbeda beda didasarkan keikut sertaan dari kelompok profesi dan jumlah orang terhadap jenis komponen yang dikerjakan. Menyadari akan hal itu, maka dirasa perlu dilakukan penelitian yang bertujuan untuk menambah kekurangan dengan cara melakukan penelitian langsung terhadap beberapa pekerja di sektor perusahaan jasa konstruksi swasta guna mendapatkan faktor yang menjelaskan nilai produktivitas kelompok kerja aktual yang sesungguhnya terjadi di lapangan. Dengan demikian, peningkatan produktivitas tenaga kerja di jasa konstruksi akan mudah dilakukan estimasi biaya yang mendekati realitas kerja, sehingga dapat dijadikan pertimbangan dan perbaikan dalam menenukan estimasi biaya produksi kerja.

\section{METODE}

Data hasil Penelitian diperoleh melalui rancangan survei dan observasi dari setiap jenis pekerjaan mulai pekerjaan galian tanah, pasangan anstampeng batu kali, pasangan pondasi batu kali, dan pasangan rolaag bata diatas pondasi pada konstruksi banguan tak bertingkat yang dikerjakan oleh kelompok pekerja pada pengembang perumahan. Dengan mempertimbangkan kegiatan kerja dilakukan dengan cara hampir sama saat melaksanakan jenis pekerjaan bangunan dan dilanjutkan pengamatan yang cukup waktu saat observasi pekerjaan sedang dikerjakan. Dilihat dari variabel teliti, memiliki ciri hubungan kausal (causal relationship) untuk menguji hubungan antara variabel-variabel internal muncul dari pekerja dan eksternal tenaga kerja, berupa variabel so- 
sio ekonomi dan lingkungan sarana kerja yang muncul dari jenis profesi mulai pembantu tukang, tukang, mandor dan pelaksana dalam meningkatkan produktivitas kerja pada jenis pekerjaan bangunan.

Populasi perusahaan pengembang perumahan yang berada di Kota Malang. perolehan sampel perusahaan pengembang dipilih secara sampling acak, perusahaan pengembang yang membangun rumah kelompok rumah tak bertingkat dalam skala minimal 30 rumah. Dipilih sebanyak 7 (tujuh) jasa pengembang dari populasi yang ada. Sampel tenaga kerja diperoleh dari 20 orang responden dari masing jenis profesi pekerja bangunan, meliputi pekerja, tukang, mandor dan pelaksana,dengan sasaran obyek pekerjaaan pengalian tanah, pasangan pondasi, padangan anstampeng pondasi dan pasangan rolaag

Data diperoleh melalui kuesioner, dengan wawancara, observasi langsung hasil kerja, dan dokumentasi. Kuesioner berisi pertanyaan dan pernyataan dari indikator-indikator variabel penelitian yang meliputi: sosio ekonomi, lingkungan kerja. Wawancara dilakukan terhadap 4 profesi pekerja bangunan dan terdiri dari pekerja pembantu tukang, tukang, mandor dan pelaksana yang bekerja langsung disektor bangunan. Observasi dan dokumentasi dilakukan pada pagi, siang dan sore hari pada waktu-waktu kerja mulai pukul 07.30 hingga pukul 15.30 (7 jam efektif). Waktu efektif dihitung dalam satuan hari kerja (satu hari kerja setara dengan 7 jam kerja efektif). Perhitungan ini didasarkan pada jam kerja mulai pukul 07.30 hingga 15.30 dengan reduksi dua jam, masing-masing satu jam untuk istirahat (dari jam 12.00-13.00). Sedangkan jenis pekejaan diamati meliputi pekerjaan tanah, pekejaan komponen pondasi.

Hubungan yang menunjukan pengaruh antara vaiabel sosio ekonomi, lingkungan sarana kerja terhadap hasil capaian kerja setiap jenis pekerjaan galian tanah, pemasngan anstampeng, pondasi dan pemasangan rollag pondasi dilakukan dengan regresi berganda melalui suatu model statistik untuk menghasilkan hubungan dari beberapa variabel bebas terhadap sebuah variabel terikat (Solimun, 2002 dalam sugiyanto 2013). Ciri-ciri analisis ini adalah: Input data, data dari observable variable atau merupakan skor faktor dari indicator variabel latent. Data yang dianalisis adalah data mentah (raw data) yang sudah diskoring berdasarkan hasil jawaban responden. Untuk variabel dependen berupa data hasil pengukuran berupa hasil capaian kerja bangunan pada setiap jenis pekerjaan dalam kurun 7 $\mathrm{jam} / \mathrm{hari}$ dan variabel independen berupa data kategori berupa jawaban bebas dari pengisian data dengan skala likert. Metode estimasi disederhanakan persamaan model yang secara matematis ditulis sebagai berikut:

$$
y=\alpha+\beta_{1} x_{1}+\beta_{2} x_{2}+\beta_{3} x_{3}+\ldots \ldots \ldots \beta_{n} x_{n}
$$

Keterangan:

$\mathrm{y}=$ variabel terikat,

$\mathrm{x}=$ variabel independen

$\alpha=$ konstanta

$\beta=$ koefisien sumbangan dari variabel

Dari rumusan diatas akan diperoleh persamaan regresi liner yang mengambarkan nilai sumbangan dari variabel bebas terhadap besaran hasil kerja dalam kelompok dari jenis pekerjaan bangunan. Variabel-variabel yang mempengaruhi produktivitas hasil kerja sektor bangunan dapat disajikan pada Tabel 1.1 


\begin{tabular}{|c|c|c|c|c|c|}
\hline Tujuan & $\begin{array}{c}\text { Analisis dan uji } \\
\text { Statistik } \\
\end{array}$ & $\begin{array}{c}\text { Konsep } \\
\text { Variabel } \\
\end{array}$ & Sub Variabel & Sumber data & $\begin{array}{c}\text { Hasil yang } \\
\text { dicapai }\end{array}$ \\
\hline \multirow{2}{*}{$\begin{array}{l}\text { 1.Mengetahui } \\
\text { model produk- } \\
\text { tivitas tenaga } \\
\text { kerja dari } \\
\text { jenis pekerjaan } \\
\text { komponen ban- } \\
\text { gunan pemuki- } \\
\text { man. }\end{array}$} & Uji korelasi & $\begin{array}{l}\text { Produktifitas } \\
\text { tenaga kerja } \\
\text { konstruksi }\end{array}$ & $\begin{array}{l}\text { - Produktifitas kerja } \\
\text { Pekerjaan tanah, pas- } \\
\text { angan pondasi, anstam- } \\
\text { peng pemukiman }\end{array}$ & $\begin{array}{l}\text { Data sekunder } \\
\text { dari perusa- } \\
\text { haan, dinas, } \\
\text { lembaga } \\
\text { perumahan }\end{array}$ & $\begin{array}{l}\text { prediksi } \\
\text { produktifi- } \\
\text { tas kerja dari } \\
\text { profesi. }\end{array}$ \\
\hline & $\begin{array}{l}\text { Regresi linier } \\
\text { berganda dalam } \\
\text { model analisis } \\
\text { regresi }\end{array}$ & Sosio ekonomi & - Pendapatan keluarga & $\begin{array}{l}\text { Data primer } \\
\text { dari survey } \\
\text { observasi hasil } \\
\text { kerja }\end{array}$ & $\begin{array}{l}\text { koefisien upah } \\
\text { kerja di } 4 \text { je- } \\
\text { nis pekerjaan } \\
\text { tanah pondasi } \\
\text { anstampeng } \\
\text { dan rolag } \\
\text { rumah tak } \\
\text { bertingkat }\end{array}$ \\
\hline $\begin{array}{l}\text { 2. Mengeta- } \\
\text { hui koefisien } \\
\text { pengupahan } \\
\text { dari profesi pe- } \\
\text { kerja bangunan } \\
\text { pemukiman }\end{array}$ & Analisis excel & $\begin{array}{l}\text { Lingkungan } \\
\text { sarana kerja }\end{array}$ & $\begin{array}{l}\text { - Pengalaman kerja } \\
\text { - TingkatPendidikan } \\
\text { - Pelatihan Ketrampi- } \\
\text { lan kerja } \\
\text { - Upah satuan kerja } \\
\text { - Umur saat kerja } \\
\text { - Penataan site lokasi } \\
\text { kerja } \\
\text { - jarak timbun material } \\
\text { - site lokasi konstruksi } \\
\text { - Ketersediaan mate- } \\
\text { rial } \\
\text { - Peralatan bantu kerja } \\
\text { - metode pelaksanaan } \\
\text { kerja } \\
\text { - kondisi cuaca } \\
\text { - Profesi kerja ban- } \\
\text { gunan }\end{array}$ & & \\
\hline
\end{tabular}

Tahapan analisis instrumen varibel dilakukan melalui korelasi dan dilanjutkan melalui statistik regresi untuk mendapatkan sumbangan hubungan dari beberapa variabel yang memberikan sumbangan terhadap produktivitas kerja. Dan koefisiean pengupahan didasarkan hasil kerja real konstruksi dengan variasi komposisi pekerja yang terlibat langsung dilapangan.

\section{HASIL}

Bagian ini menyajikan hasil analisis pada kategori bangunan rumah tidak berting- kat yang dikerjakan oleh profesi pekerja bangunan meliputi; pekerja, tukang, mandor dan pelaksana pada sub bidang pekerjaan tanah dan komponen pondasi batu kali yang dapat dipengaruh secara dominan oleh variabel sosioekonomi, lingkungan kerja. Hasil uji korelasi kelompok variabel sosio-ekonomi,lingkungan sarana kerja diperoleh nilai r-valui dari masing masing profesi pekerja ditunjukan pada Tabel 1.1. 


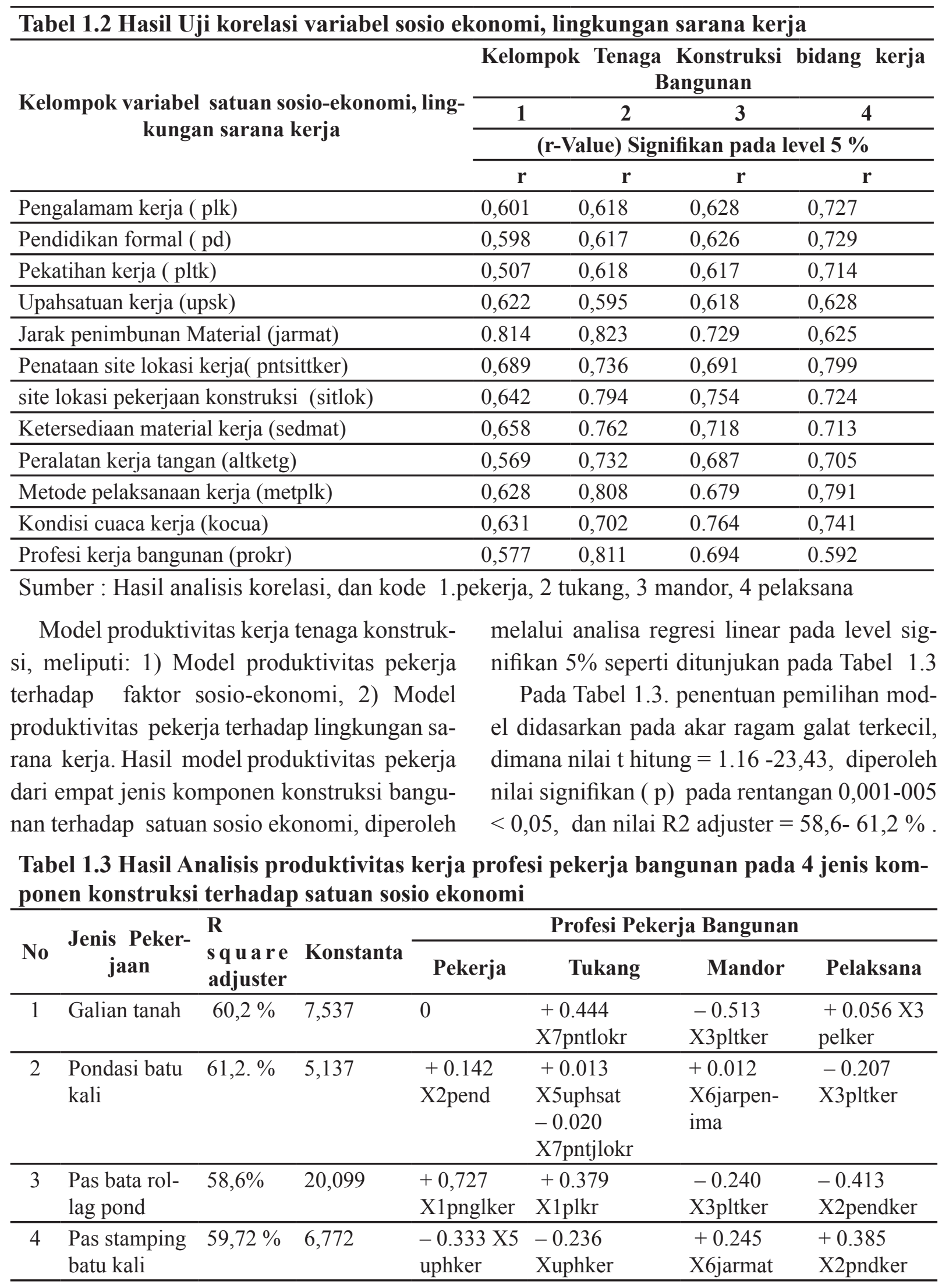

Sumber : Hasil Analisis 
sumbangan variabel pada produktivitas kerja dari profesi pekerja bangunan untuk 4 jenis pekerjaaan konstruksi dibentuk sebesar 58,6 sampai 61.2 oleh variabel meliputi: Lama pengalaman dalam bekerja dalam sector konstruksi (X1), pendidikan formal yang dicapai sebelum bekerja (X2), Pelatihan ketrampilan kerja yang pernah dilakukan dari teman sejawat saat kerja(X3), Upah satuan kerja (X5), Jarak tempat timbun material ke tempat pasangan (X6). Penataan site lokasi material kerja (X7)

Model produktivitas kinerja tenaga pekerja dari empat jenis komponen konstruksi terhadap kelengkapan lingkungan sarana kerja, dengan hasil diperoleh melalui analisa regresi linear pada level signifikan 5\% seperti ditunjukan pada Tabel 1.4 dibentuk oleh variabel sebesar 62,8 sampai $71,6 \%$ meliputi : site lokasi kerja komponen pasangan (X1), Ketersediaan material kerja komponen bangunan (X2), Jarak material terhadap pekerjaan komponen (X3), peralatan kerja yang dimiliki sesuai profesi $\mathrm{X} 4$ ), cara metode kerja saat mengawali pekerjaan (X5), Profesi dalam bekerja rutin bangunan (X9.

Estimasi Koefisian upah pekerja berdasarkan Produktivitas kerja real dari 4 jenis Pekerjaan komponen Bangunan.

Penentuan koefisien produktivitas kerja bagi profesi pekerja, tukang, kepala tukang/ mandor dan pelaksana, diperoleh berdasarkan komposisi perbandingan antara pekerja dengan tukang, mandor dan pelaksana bangunan dalam melaksanakan pekerjaan persatuan jam

Tabel 1.4. Hasil Analisa produktivitas kerja profesi pekerja Bangunan dari empat jenis komponen konstruksi terhadap lingkungan sarana kerja

\begin{tabular}{|c|c|c|c|c|c|c|c|}
\hline \multirow{2}{*}{ No } & \multirow{2}{*}{$\begin{array}{c}\text { Jenis Peker- } \\
\text { jaaan }\end{array}$} & \multirow{2}{*}{$\begin{array}{l}R \text { sguare } \\
\text { adjuster }\end{array}$} & \multirow{2}{*}{ konstanta } & \multicolumn{4}{|c|}{ Profesi Pekerja Bangunan } \\
\hline & & & & Pekerja & Tukang & Mandor & Pelaksana \\
\hline \multirow[t]{2}{*}{1} & Galian tanah & $62.45 \%$ & 7,047 & 0 & +1.179 & +0.528 & $+0.038 \times 9$ \\
\hline & & & & & $\mathrm{X} 1$ sit kerja & $\begin{array}{l}\text { X6kon- } \\
\text { cuaca }\end{array}$ & profkerr \\
\hline \multirow[t]{2}{*}{2} & Pondasi batu & $71,6 \%$ & 4,724 & -0.191 & +0.538 & -0.022 & +0.038 \\
\hline & kali & & & X9profkr & X4alatker & $\begin{array}{l}\mathrm{X} 2 \text { sedma- } \\
\text { ter }\end{array}$ & X5metkerak \\
\hline \multirow[t]{4}{*}{3} & Pas batarollag & $64,34 \%$ & 19,891 & -1.000 & +0.524 & -0.021 & -0.524 \\
\hline & pond & & & X9profe- & X4alkrtg & $\mathrm{X} 1$ sitker & X2sedmat \\
\hline & & & & sikr & & & -0.273 \\
\hline & & & & & & & X4alkrtg \\
\hline \multirow[t]{2}{*}{4} & Pas stamping & $69,48 \%$ & 6,657 & -0.264 & +0.828 & +0.017 & -0.290 \\
\hline & batu kali & & & X9profker & X4alatker & X2sedmat & X1sitlok \\
\hline
\end{tabular}

Sumber : Hasil analisis

Pada Tabel 1.4. dapat diketahui kemaknaan model yang dibentuk dari nilai thitung $=1.78$ 17.45, dimana diperoleh nilai signifikan diantara $\mathrm{p}=0.001-0,05<0.05$, dan nilai R2 (terkoreksi) $=62,8-71,6 \%$. Sumbangan variabel pada model produktivitas kerja dari profesi pekerja untuk 48 jenis pekerjaaan konstruksi kerja perhari. Hasil produktifitas kerja dari profesi pekerja, tukang, kepala tukang dan pelaksana dapat direkam berdasarkan dari setiap jenis pekerjaan komponen bangunan, meliputi hasil capaian volume kerja harian,dan hasil koefisien produktifitas kerja perharian tiap unit kerja oleh masing profesi pekerja bangunan, dapat disajikan pada tabel.1.5 sebagai berikut: 
Tabel 1.5. Estimasi koefisien Upah Kerja dari 4 Jenis Pekerja komponen bangunan

\begin{tabular}{lcccccc}
\hline \multirow{2}{*}{$\begin{array}{c}\text { Jenis Pekerjaan } \\
\text { komponen bangu- } \\
\text { nan }\end{array}$} & $\begin{array}{c}\text { Hasil } \\
\text { Volume } \\
\text { kerja }\end{array}$ & $\begin{array}{c}\text { Satuan } \\
\text { peker- } \\
\text { jaan }\end{array}$ & \multicolumn{4}{c}{$\begin{array}{c}\text { Koefisien Produktifitas Profesi Pekerja Ban- } \\
\text { gunan }\end{array}$} \\
\cline { 5 - 7 } & 7 & $\mathrm{~m} 3$ & 0 & 0.452 & 0.0452 & 0.00674 \\
\hline Galian Tanah & 6.8 & $\mathrm{~m} 3$ & 0.2941 & 0.147 & 0.0147 & 0.0024 \\
\hline Pas Anstampeng & 5 & $\mathrm{~m} 3$ & 0.4 & 0.2 & 0.02 & 0.0033 \\
\hline pas pondasi & 19.9 & $\mathrm{~m} 1$ & 0.1005 & 0.0502 & 0.005 & 0.0008 \\
\hline pas Rolag bt pond & & & & & & Tukang \\
\hline
\end{tabular}

Sumber hasil analisis

Koefisien produktivitas kerja dari masing masing profesi bangunan diperoleh dalam ukuran volume yang dikerjakan bersama oleh kelompok pekerja, tukang, mandor, dan pelaksana dalam kurun waktu kurang dari 7 jam kerja sehari. Volume fisik kerja dapat diukur dalam satuan m1,m2,m3. Hasil kerja berupa volume dipakai untuk menganalisa dari masing masing jenis pekerjaan melalui kelompok profesi pekerja meliputi jenis pengalian tanah, pekerjaan pondasi batu kali, anstampeng, pasangan rolag.Perbandingan komposisi pekerja terdiri dari (2) dua pekerja berbanding 1 (satu) tukang, dan 1 (satu) mandor berbanding 10 (sepuluh) tukang, sedangkan 1 (satu) pelaksana berbanding 4 (empat) jenis pekerjaan mandor. Kriteria perbandingan sesuai dengan karakteristik jenis pekerjaan, saat kapan digunakan profesi pekerja, tukang, mandor dan pelaksana. Dari hasil tabel diatas terdapat pada kolom pekerja menunjukan angka 0 , dalam artian bahwa pada jenis pekerjaan konstruksi tersebut tidak dibutuhkan profesi pekerja, karena setiap jenis pekerjaan komponen konstruksi harus ditanggani pekerja yang memiliki skil minimal profesi tukang dengan keahlian pada bidangnya.

\section{PEMBAHASAN}

Model produktivitas kerja untuk 4 (empat) jenis pekerjaan konstruksi yang dilakukan oleh profesi bangunan meliputi profesi pekerja, tukang, mandor, dan pelaksana untuk kelompok sosio ekonomi lingkungan kerja, prasarana dan sarana kerja, keselamatan dan kelengkapan kerja. Pada kelompok sosio ekonomi model produktivitas kerja diberikan sumbangan sebesar 58,6-61,2 \% meliputi: Lama pengalaman yang dimiliki dalam bekerja 5-7 th $(68 \%)$; Pendidikan formal yang dicapai sebelum bekerja min SD (83\%), Pelatihan ketrampilan kerja yang diperoleh melalui belajar dari tukang atasan kerja (78\%); besaran upah satuan kerja yang diterima perhari standart (74\%); Jarak penimbunan material di loksi pekerjaan pasangan (79\%); penataan site lokasi material dan lokasi kerja (76\%). Dari sumbangan variabel diatas produktivitas kerja yang dihasilkan dalam mengerjakan setiap jenis pekerjaan ditentukan dari pengalamam bekerja disektor konstuksi bangunan, memberikan rutinitas yang telah dilakukan meliputi kesiapan material sebelum dipasang dan saat membuat material baru untuk pekerjan lanjutan, pendidikan yang telah dicapai pekerja, hal ini sangat terkait dengan pemahaman instruksi selama pengarahan kerja, meliputi keajekan dalam memahami pengolahan material dan cara pelaksanaan, dalam menjalakan jenis pekerjaan secara berulang dari waktu ke waktu selama menjadi pekerja bangunan 
baik yang diperoleh melalui teman profesi atau tukang atasan langsung. Jarakpenimbunan material saat kendaraan menurunkan dan menenpatkan material harus dilakukan oleh kelompok kerja terutama mandor dan pelaksana, kemudahan jarak pengambilan material dapat mendukung ketepatan waktu kegiatan kerja saat dimulai kerja sampai akhir waktu kerja. Penataan site lokasi material dan lalu lintas pekerjaan konstruksi yang dilakukan dapat mengurangi resiko waktu molor kerja, kondisi lokasi kerja yang mudah dijangkau oleh pekerja untuk memasuki area lpasangan komponen bangunan memberikan waktu tempuh bervariasi tergantung dari alat yang digunakan. Oleh karena itu capaian produktivitas kerja bagi profesi pekerja bangunan sangat komplek dalam meningkatkan produktivitas volume kerja harian yang dicapai dalam kelompok kerja di empat jenis pekerjaaan komponen konstruksi. Dikemukakan oleh Ravianto (1999) bahwa pada dasarnya bekerja mencakup sikap mental, pandangan bahwa antara lain cara kehidupan hari ini harus lebih baik dari cara kerja kemarin dan hasil yang dicapai harus lebih baik dari yang diperoleh hari ini. selanjutnya dikemukakan pula bahwa variabel yang mempengaruhi produktivitas tenaga kerja secara langsung maupun tidak langsung digolongkan menjadi antara lain factor utama, yaitu; pendidikan dan pelatihan, pengalaman, kesehatan kerja, pengahasilan, janinan social, manajerial kerja, kesempatan dan penghargaan kerja. Sejalan dengan Suharto (1995) sumbangan variabel yang mempengaruhi produktivitas tenaga kerja di lapangan dikelompokan meliputi; kondisi lahan lokasi kerja, sarana bantu kerja, jumlah kelompok dalam kerja, pengalaman yang dimiliki pekerja, dan kepadatan kerapatan saat menger- jakan pekerjaan dari jumlah tenaga kerja.

Dari sisi lain pengolahan sumber daya yang ada dalam suatu kegiatan pekerjaan terdiri atas sumber daya manusia dan sumber daya non manusia. Efisiensi pemanfaatan sumber daya manusia pada proyek konstruksi perumahan dapat dilakukan melalui penerapan manajemen proyek dan sumber daya pekerja yang dibutuhan dengan cara pembentukan kelompok kerja yang sesuai dengan jenis pekerjaaan yang memerlukan kekhususan nonskill dalam artian kerja otot lebih banyak dari otak dan juga jenis pekerjaan yang dibutuhkan ketrampilan dan skill, sehingga terbentuk komposisi kelompok kerja pekerja dan tukang akan memberikan kontribusi dari capain pekerjaan, serta lintas kelompok bidang kerja secara bersama sama dalam mewujudkan komponen konstruksi sehingga tujuan dari produktivitas kerja dalam arti capain volume fisik terpenuhi. Seperti dijelaskan oleh Ratnayanti (2003) bahwa pada kenyataan yang terjadi di lapangan, hanya tukang yang menghasilkan produk, sedangkan pekerja (pembantu tukang) bersifat mendukung kelancaran pekerjaan tukang. Tentunya dalam artian pendukung memberikan pelayanan mulai ketersediaan bahan jadi berupa adonan sampai pada bahan komponen dipasangkan menjadi konstruksi bangunan, sehingga konstruksi akan terwujud selalu diperlukan kebersamaan, hal ini sejalan Sejalan yang dikemukakan oleh Heidjrachman dan Husnan (2002) mengemukakan beberapa factor mengenai kebutuhan dan keinginan pegawai yakni; gaji yang baik, pekerjaan yang aman, rekan team kerja yang kompak, penghargaan terhadap pekerjaan, pimpinan yang adil dan bijak, pengarahan dan perintah yang wajar dari atasan, organisasi kerja atau tempat kerja yang dihargai oleh masyarakat. Hal ini 
pula menunjukkan bahwa kenyataan yang terjadi di lapangan, yang nampak berperan hanya tukang yang menghasilkan produk. namun untuk pekerjaan $\urcorner$ - pekerjaan yang memerlukan 'kekhususan' yang pengadaannya tidak/ masih memerlukan 'skill' tertentu, mulai dari cara mencampur, cara, cara menyiapkan bata kali sebelum dipasang, cara menyiapkan tegal sebelum dipasangkan, cara mengusung material, cara meladeni sebelum luluh siap dipasangkan pada elemen konstruksi, sangat diperlukan pekerja/pembantu/pelayan untuk menyiapkan, sehingga tukang didalam melakukan pekerjaan dapat mencapai nilai produktifitas optimal.

Melalui komposisi sejumlah pekerja yang dapat mendukung produk sesuai dengan jenis dari masing masing pekerjaan agar capain volume fisik dapat maksimal dari tukang. misal termasuk pada kategori pekerjaan yang diperlukan pembantu kerja, ini meliputi: pasang anstampeng, batu kali. Sedangkan untuk pekerjaan yang membutuhkan ,skill', pada pelaksanaan pekerjaan tertentu, dapat diketahui bahwa pekerjaan tersebut lebih mencapai optimal produktivitasnya bila dilakukan sendiri oleh tukang. Hal ini karena ada pekerjaan yang menuntut 'skill', bila seorang tukang dibantu oleh pekerja yang tidak menguasai 'skill', maka dari hasil penelitian (Tjaturono, 2003) dalam mewujudkan produk kerja sangat diperlukan kekompakan dari satuan kerja dan dukungan pula dari team kelampok lain dari jenis pekerjaan yang sejenis, maupun berbeda jenis tapi memiliki motivasi, komitmen, komunikasi, kesepakata kerja untuk memproduksi komponen konstruksi, sehingga menunjukkan bahwa produktivitas pada pekerjaan dari jenis tertentu yang dihasilkan lebih rendah dari pada produktivitas bila dilakukan tanpa pembantu/pekerja.
Pada kelompok lingkungan sarana kerja memberikan sumbangan atribut sebesar 62,8 - 71,6 \% untuk empat jenis pekerjaan konstruksi, variabel berpengaruh terhadap model produktivitas kerja oleh profesi bangunan meliputi pekerja, tukang, mandor, dan pelaksana bangunan, meliputi variabel: site lokasi kerja konstruksi yang mudah tanpa halangan pekerjaan lain berjalan (76\%); Ketersediaan material sebelum pekerjaan dimulai oleh pekerja, tukang, mandor dan pelaksan saat akan mengawali pekerjaan konstruksi sesuai dengan kebutuhan volume kerja yang akan dicapai (74\%); Kelengkapan peralatan kerja bantu yang dimiliki oleh masing profesi adalah milik sendiri berupa alat kerja tangan, tidak semua alat bantu di penuhi oleh pekerja dan masih disediakan oleh pengembang(76\%); Dilakukan pengarahan oleh mandor pelaksana tentang carametode kerja saat mengawali pekerjaan dalam mengunakan material dan proses kerja (72\%), Kondisi cuaca saat berlangsung jam kerja komponen konstruksi dimana kondisi cuaca baik, dan kondisi hujan tidak menggangu atau menggangu selama pekerjaan berlangsung (62\%); status profesi sebagai pekerja bangunan sejati dimiliki sebagai tenaga kerja disektor bangunan tidak melalukan pekerjaan sampingan misal saat tandur tidak masuk kerja (87\%); Semua atribut diatas yang memberikan sumbangan dari produktivitas kerja oleh pekerja profesi merupakan cerminan dari hasil dari proses kerja mulai dari menyiapkan bahan, situasi lokasi kerja sampai pada perakitan komponen jadi yang menunjukan keadaan sesungguhnya dari pekerja dalam mendukung tercapainya kemampuan kerja. Ditegaskan dalam Undang Undang No 8 tahun 1999 mengatur tentang kewajiban penyelenggara konstruksi untuk memenuhi 
ketentuan tentang keteknikan, keamanan, keselamatan, perlindungan tenaga kerja dan tata lingkungan setempat kerja (Direktorat jenderal pos dan telekomunikasi, 2007). Pengaturan Tata lingkungan kerja yang memberikan akses kemudaan dalam menjalankan aktivitas dari mulai tata lokasi pekerjaan, ketersediaan bahan material yang dikerjakan sebelum pekerjaan dimulai, jarak penimbunan material terhadap lokasi pekerjaan konstruksi, kelengkapan alat bantu kerja, sangat menentukan dalam mendukung dan meningkatkan produk kerja. Sejalan yang dikemukakan oleh Heidjrachman dan Husnan (2002) terdapat beberapa faktor mengenai kebutuhan dan keinginan pegawai yakni; gaji yang sesuai, lokasi kerja yang aman, team rekan kerja yang kompak, penghargaan terhadap pekerjaan, pimpinan yang adil dan bijak, pengarahan dan perintah yang wajar, organisasi atau tempat kerja yang dihargai oleh masyarakat.

Setiap capaian fisik bangunan melalui hasil produktifitas kerja yang dilakukan oleh pekerja, tukang kepala tukang, mandor, dan pelaksana memperoleh volume hasil pekerjaan real dalam kurun waktu 7 jam kerja perhari. Capain kerja menunjukan dan mengambarkan kerja real dari setiap jenis pekerjaan komponen pada bangunan tak bertingkat yang dilakukan oleh kelompok pekerja bangunan berupa hasil volume kerja. Setelah dilakukan analisis nilai produk kerja, maka memperoleh koefisien produk kerja sebagai dasar untuk pengupahan dari masing masing kelompok pekerja, tukang, kepala tukang dan pelaksana sesuai jenis pekerjaaan konstruksi. Pada table 1.5 secara berturut upah koefisien kerja dari pekerjaan tanah ,pemasangan anstampeng, pemasangan pondasi dan pasang rolag. Para pengembang telah revisi satuan produktivitas tenaga kerja berdasarkan pada modifikasi produktivitas dan pengalaman masing masing oleh Zainal, (1992) dan Soedradjat, (1984). Selanjutnya Departemen Pekerjaan Umum Pusat Penelitan dan Pengembangan Pemukiman pada tahun 19921993 menentukan produktivitas tenaga kerja di bidang konstruksi perumahan. dalam SNI 200. Menurut SNI 2001 produktivitas tenaga kerja galian tanah biasa adalah sebesar 3-5 m3 per hari. Capaian realitas produk kerja setiap jenis pekerjaan yang dihasilkan dalam kurun waktu 7 jam kerja perhari. Dasar penentuan angka koefisien upah pekerjaan tanah $0,75 \mathrm{x}$ upah perhari dan komposisi pekerjaan didasarkan pada jenis pekerjaaan. misal perbandingan 2 pekerja berbanding 1 tukang, sedangkan 20 tukang berbanding 1 mandor, dan 1 pelaksana. ( John.W Niron,1980). Biaya buruh akan sangat dipengaruhi antara lain panjang waktu kerja yang diperlukan, keadaan tempat kerja, ketrampilan dari pekerja, sikap dan profesi kerja. Pendapat dari Soedrajat. (1984), tentang menaksirkan upah kerja didasarkan perolehan jam kerja berupa besaran upah perjam dikalikan volume capaian sebagai tolok ukur menentukan upah perhari dan komposisi jumlah pekerja dalam setiap jenis pekerjaan. untuk pekerjaan galian tanah sedang dengan alat bantu tangan diperoleh kapasitas hasil kerja 0,75 - 1,5 M3/jam kerja. Hasil kajian dari Optima Nus dalam Darmawan. (1986) menjelaskan dalam bangunan tak bertingkat jumlah komposisi pekerja dari jenis pekerjaan untuk setiap komponen bangunan didasarkan pada kondisi real bekerja, saat kapan mengunakan komposisi perbandingan pekerja. Pada jenis pekerjaan pasangan perbandingan komposisi 2 pekerja berbanding 1 tukang berbanding 1 mandor dan 1 pelaksana. Kegiatan ini akan berbeda untuk jenis pekerjaan 
komponen konstruksi yang lain. misal pengalian tanah, pengolahan kayu komponen bangunan, almunium galvalum dan pengecatan.

Komposisi pekerja, tukang dan mandor, pelaksana bangunan, dan kondisi selama pelaksanaan berlangsung meliputi lokasi medan cuaca dan asumsi pekerjaan dilakukan secara wajar sesuai etika kerja, dapatlah diperoleh hasil yang dapat dipertimbangkan dengan membandingkan upah harian standart umum yang diberlakukan pada pengupahan buruh bangunan dikota Malang. Tentunya ini membuktikan bahwa setiap daerah memiliki karakteristik dari capaian volumen kerja berdasarkan kondisi internal pekerja,dan external pekerja selama melakukan aktivitas bekerja yang mungkin mempengaruhi produktivitas kerja dan perolehan standart upah kerja harian yang diperoleh, minimal diatas UMR lokasi kota/ kabupaten.

\section{SIMPULAN}

Berdasarkan hasil pembahasan produktifitas kerja sector bangunan tak bertingkat, dapa direkomenasikan (1)Kelompok sosioekonomi pada profesi pekerja tukang, mandor dan pelaksana memberikan sumbangan model produktivitas kerja sebesar, diantara 58,6\% - 61,2 \% untuk empat jenis pekerjaan komponen konstruksi bangunan yang berpengaruh terhadap produktivitas kerja. Sumbangan atribut yang mendukung kelompok sosio ekonomi meliputi: pengalamam profesi pekerja antara 5-7 th; Pendidikan formal yang dicapai sebelum bekerja min $\mathrm{SD} /$ madrasah; pelatihan ketrampilan kerja yang dilakukan melalui belajar dari tukang atasan kerja; upah kerja dari masing masing profesi pekerja persatuan harian; Jarak material yang di timbun dilokasi pekerjaan terhadap tempat pekerjaan kompo- nen konstruksi; dan pentaan site lokasi tempat material dan sirkulasi kerja konstruksi. Sedangkan (2) kelompok lingkungan sarana kerja pada memberikan sumbangan model produktivitas kerja sebesar, diantara 62,8-71,6\% untuk empat jenis pekerjaan komponen konstruksi bangunan yang berpengaruh terhadap produktivitas kerja, meliputi variabel : site lokasi kerjapemasangan kosntruksi terhadap pekerja kontruksi yang lain tertata sesuai peruntukan kerja; Ketersediaan material sebelum pekerjaan komponen konstruksi sesuai kebutuhan volume kerja; Kelengkapan peralatan kerja bantu yang dimiliki oleh masing profesi alat bantu di penuhi oleh pekerja; Pengarahan sebelum pekerjaan dimulai oleh mandor tentang cara metode kerja pemakain material dan mengawali pekerjaan; Kondisi cuaca saat berlangsung jam kerja untuk pembuatan komponen konstruksi cuaca baik, hujan rintih tapi tidak menggangu kegiatan pekerjaan; profesi pekerja bangunan sebagai tenaga kerja disektor bangunan. Dan (3) Koefisien upah dari produk kerja real dilapangan merupakan ukuran hak pengupahan yang diberikan kepada masing profesi, dapat dipertimbangkan untuk menghasilkan berupa koefisien pengupahan kerja dalam ukuran waktu kerja 7 jam perehari untuk 4 jenis kegiatan pekerjaan komponen konstruksi bangunan. Saran yang perlu dipertimbangkan meliputi: (1) atribut sosio ekonomi pada lingkup aspek kematangan psikologi dari peraturan tenaga kerja (2) mengembangkan dari sisi kualitas bahan yang akan digunakan

\section{DAFTAR RUJUKAN}

Anonim (2007) Undang undang No 8 tahun 1999, keselamatan dan kesehatan kerja. Di rektorat Jenderal Pos dan Telekomunikasi Budiharto dan Lili S, (1993), "Pengkajian 
24 JURNAL BANGUNAN, VOL. 25, NO.2, OKTOBER 2020: 11-24

Produktivitas Tenaga Kerja dalam Pemban gunan Perumahan dan Gedung" (Proyek Akhir Penelitian Analisis Biaya Konstruk si), Laporan, Departemen Pekerjaan Umum, Badan Penelitian dan Pengemban gan P U, Pusat Penelitian dan Pengemban gan Pemukiman.

Hafid, (1995), "Studi Pengukuran Produk tivitas Tenaga Kerja dengan Menggunakan Pendekatan Analisa Rasio", Usahawan, No. 04 Tahun XXIV April.

Halligan, David W., Laura A. Demsetz, James D. Boown, dan Clark B. Pace, (1994), ”Ac tion Response Model and Loss of Produc tivity in Construction", Volume 120 no. 1: 47-62, Journal of Cunstruction Engineering and Management, ASCE.

Kaming, P.F., Wikantyasningsih, A., Syatanto (1998), "Studi tentang Perbandingan Produktivitas Tenaga Kerja Konstruksi di Yogyakarta dan Sekitarnya”, Konferensi Manajemen Proyek Konstruksi

Ratnayanti, R, (2003), 'Produktivitas Tenaga Kerja Konstruksi pada Setiap Jenjang Ke ahlian di Lapangan", Jurnal Teknik Sipil ITB, Volume 1, no.1, April 2003.

Ravianto, J.P, (1999), "Produktivitas dan Tenaga Kerja Indonesia”, Lembaga Sarana Informasi Usaha dan Produktivitas, Jakarta. Rostiyanti, S. F., (2001), "Pengaruh Umur dan Pengalaman terhadap Koefisien $\mathrm{Tu}$ kang Batu pada Pekerjaan Pasangan Dind ing Batu Merah", Jurnal Teknik Sipil Uni versitas Tarumanegara, no. 3 November 2001, Jakarta.

Sanders, Steve R., dan H. Randolph Thomas, (1993), "Masonry Productivity Forecasting Model", Volume 119 no. 1: 163-178, Jour nal of Construction Engineering and Mangement, ASCE.

Suharto, L, (1995), Manajemen Proyek: dari konseptual sampai operasional. Erlangga. Sutikno, (2000), "Analisa Produktivitas Kelompok Kerja untuk Pekerjaan Pasangan Dinding Batu Bata di Proyek Perumahan", Tesis P rogram Pasca Sarjana Institut Teknologi Sepuluh November, Surabaya. Tangen, Stefan, (2002), "Understanding The Concept of Productivity", Proceedings of the 7th Asia Pacific Industrial Engineering and Management Systems Conference, Taipe.

Thomas, H.R., (2000) "Schedule Accelera tion, Work Flow and Labor Productiv ity”, Volume 126 no. 4: 261-267, Journal of Construction Engineering and Manage ment, ASCE.

Tjaturnoro, Nadjadji A. dan Indrasurya B.M., (2003), "Evaluasi Produktifitas Tenaga Kerja Berdasarkan Delapan Faktor Internal Dibandingkan Dengan Standart BOW 1921 dan SNI 2001 Pada Pembangunan Rumah Menengah di Jawa Timur", Jurnal Teknik Sipil Universitas Tarumanegara Jakarta, Maret 2004 